\title{
Cytotoxic and Apoptotic-inducing Effect of Fraction Containing Brazilein from Caesalpinia sappan L. and Cisplatin on T47D Cell Lines
}

\author{
Prisnu Tirtanirmala, Annisa Novarina, Rohmad Yudi Utomo, Raisatun Nisa \\ Sugiyanto, Riris Istighfari Jenie, Edy Meiyanto* \\ Cancer Chemoprevention Research Center (CCRC), Faculty of Pharmacy, \\ Universitas Gadjah Mada, Indonesia
}

\begin{abstract}
Anticancer activity of secang's heartwood (Caesalpinia sappan L.) is based on its main compound: brazilin and brazilein. Brazilin, brazilein, and other compounds such as caesalpiniaphenol can affect proteins that have a role in apoptosis. In this study, we observed cytotoxic activity of fraction containing brazilein (FCB) alone or in combination with chemotherapeutic agent, cisplatin and the ability of the combination to induce apoptosis in T47D breast cancer cell lines. Cytotoxicity assay was determined using MTT assay, whereas the detection apoptosis induction was conducted using flow cytometry using Annexin- $V$ and propidium iodide. FCB and cisplatin showed cytotoxic effect on T47D cells with IC 50 value of $68 \mu \mathrm{g} / \mathrm{mL}$ and $16 \mu \mathrm{M}$, respectively. Combination of FCB and cisplatin result synergistic combination at the concentration ratio of $\mathrm{I} / 2 \mathrm{IC} 50$ with $\mathrm{Cl}$ value of 0.66 . Its combination also able to induce apoptosis on T47D cell population 13\% larger than the single treatment. Based on this study, we conclude that FCB is able to enhance the cytotoxic effects of cisplatin by inducing apoptosis.
\end{abstract}

Keywords: Caesalpinia sappan L., cisplatin, apoptosis, breast cancer

\section{INTRODUCTION}

Among women, breast cancer has the highest cancer incidence in seven Asian countries including Indonesia. Cisplatin is a chemotherapeutic agent that commonly used in the treatment of various types of cancer, including breast cancer (Tsimberidou, et al., 2009; Dhar, et al., 2011). However, many anticancer drugs have narrow therapeutic index, so they can lead to multidrug resistance (MDR) (Ismael, et al., 2008). They also cause side effects such as nephrotoxicity, neurotoxicity (Milosavlievic, et al., 2010), and others. The use of co-chemotherapeutic agent combined with chemotherapeutic agent can improve the effectiveness of cancer therapy as well as reduce side effects (Sharma, et al., 2004).

One of the plants that potentially developed as an co-chemotherapeutic agent is secang's heartwood (Caesalpinia sappan L.). Previous research proved that the main component of phenolic Caesalpinia sappan L., is homoisoflavonoid like brazilein, chalcone, protosappanin and brazilin (Yan, et al., 2005;
Shimokawa, et al., 1985; Washiyama, et al., 2009). Brazilein has cytotoxic effects on skin cancer cells to induce apoptosis through caspase-3-dependent (Liang, et al., 2013).

This study observed the cytotoxic effect and apoptosis induction of fraction containing brazilein (FCB) and its combination with cisplatin against T47D breast cancer cells. By doing this research, the results is expected to be a reference for further research in order to explore compound/active fraction of secang's heartwood as cisplatin co-chemotherapeutic agent in the breast cancer treatment.

\section{MATERIALS AND METHODS}

\section{Sample Preparation}

FCB was obtained from the collection of Cancer Chemoprevention Research Center (CCRC), Universitas Gadjah Mada. Cisplatin (Wako) was used as chemotherapeutic agent with concentration $1 \mathrm{mg} / \mathrm{mL}$.

\footnotetext{
*Corresponding author email: meiyan_e@yahoo.com
} 
Both FCB and cisplatin were diluted in various concentration using Dulbecco's Modified Eagle Medium (DMEM) high glucose culture medium before treated to the cell. FCB was dissolved first in dimethyl sulfoxide (DMSO) as co-solvent with final concentration $5 \mathrm{mg} / \mathrm{mL}$.

\section{Cells Culture}

Human breast cancer T47D culture cells were collection of Cancer Chemoprevention Research Center (CCRC), Universitas Gadjah Mada. The cell line was kindly given by Prof. Kawaichi, Nara Institute of Science and Technology (NAIST), Japan.

\section{Chemicals}

T47D cell lines were cultured in DMEM high glucose (Invitrogen) with Fetal Bovine Serum (FBS) $10 \%$ (Gibco), penicilinstreptomycin $1.5 \%$ (Gibco), and fungizone $0.5 \%$ (Gibco). Trypsin-EDTA $0.25 \%$ (Gibco) was used to detach the cells from tissue culture dish. Phosphate buffer saline (PBS) was used as washing solution. DMSO (Sigma) was used to dissolve the test solution in concentration less than $1 \%$. For cytotoxicity assay, MTT (3-[4,5dimethylthiazol-2-yl]-2,5diphenyl tetrazolium bromide) reagent (Sigma) $5 \mathrm{mg} / \mathrm{mL}$ was dissolved in DMEM medium. Sodium dodecyl sulfate (SDS)-HCl $0.01 \mathrm{~N}$ was used as stopper reagent. For apoptosis assay, we used reagent kit from Biovision.

\section{Cytotoxic Assay}

Cells (briefly $6 \times 10^{3}$ cells/well) were transferred in to six well tissue culture plate (Iwaki) and incubated for $24 \mathrm{~h}$. Cells were treated with FCB (concentration 20; 50; 75 and $100 \mu \mathrm{g} / \mathrm{mL}$ ), cisplatin (concentration $1 ; 2 ; 5$; $10 ; 15$; and $30 \mu \mathrm{M}$ ), and their combination (concentration ratio $1 / 6 ; 1 / 3$; and $1 / 2 \mathrm{IC}_{50}$ ) and then incubated for $24 \mathrm{~h}$. After 24 hours of incubation, medium was removed and cells were washed with $100 \mathrm{~mL}$ PBS. Then $100 \mathrm{~mL}$ MTT reagent with final concentration 0.5 $\mathrm{mg} / \mathrm{mL}$ in DMEM high glucose medium was added into each well and incubated again for 34 hours to form formazan crystal. The stopper reagent $(10 \%$ SDS in $0.01 \mathrm{~N} \mathrm{HCl})$ was used to dissolved and incubated overnight at room temperature and in the dark (covered with aluminum foil). The next day, the absorbance from each well was measured by ELISA reader with $595 \mathrm{~nm}$ wavelength.

\section{Apoptosis Assay}

Cells (briefly $3 \times 10^{5}$ cells/well) were transferred in to six well tissue culture plate (Iwaki) and incubated for $24 \mathrm{~h}$. Cells were treated with FCB, cisplatin, and their combination with concentration $1 / 2 \quad \mathrm{IC}_{50}$ and then incubated for $24 \mathrm{~h}$. After incubation, adherent and detached cells were collected and centrifugated at $2000 \mathrm{rpm}$ for $3 \mathrm{~min}$, then washed twice with cold PBS. Then, PBS was discarded, conical was sealed with aluminum foil, and $500 \mathrm{~mL}$ of buffer Annexin- $\mathrm{V}$ were added to conical. AnnexinV and propidium iodide reagent were added respectively by 5 $\mathrm{mL}$, incubate for 5 minutes and analyzed by using flowcytometer (BD, FACS Calibur).

\section{Data Analysis}

Single cytotoxic assay. Cell viability was determined by percent viability. The calculation is [(absorbance of treated-drug) - (absorbance of medium)/(absorbance of control (untreated) cells - absorbance of medium) $] \times 100 \%$. Linier regression between log concentration and \% cell viability giving the equation $\mathrm{Y}=\mathrm{Bx}+\mathrm{A}$ were used to calculate $\mathrm{IC}_{50}$ value. The $\mathrm{IC}_{50}$ values are defined as the drug concentrations required to reduce the absorbance by $50 \%$ of the control, Combinational cytotoxic assay, Drug Reduction Inex (DRI) and Combination Index (CI) was assessed by the Chou-Talalay method utilizing CompuSyn ${ }^{\circledR}$ software.

\section{RESULT AND DISCUSSION}

Cytotoxic assay was performed using MTT assay. The results indicated the occurrence of dose dependent manner. $\mathrm{IC}_{50}$ value that obtained for FCB single treatment is $68 \mu \mathrm{g} / \mathrm{mL}$ (Fig. 1). IC I0 $_{50}$ value that less than 100 $\mu \mathrm{g} / \mathrm{mL}$ indicates that FCB has potent cytotoxic effect against T47D cells (Omoyeni, et al., 2014). When compared with methanolic extract of Caesalpinia sappan L., FCB also has more potent cytotoxic effect because the $\mathrm{IC}_{50}$ value from methanolic extract of Caesalpinia sappan L. was $150.9 \mu \mathrm{g} / \mathrm{mL}$ (Nurulita and Muflih, 2006). Single treatment of cisplatin against T47D breast cancer cells was also conducted to determine the $\mathrm{IC}_{50}$ value. The $\mathrm{IC}_{50}$ value of cisplatin that obtained in this study is $16 \mu \mathrm{M}$ (Fig. 2). 


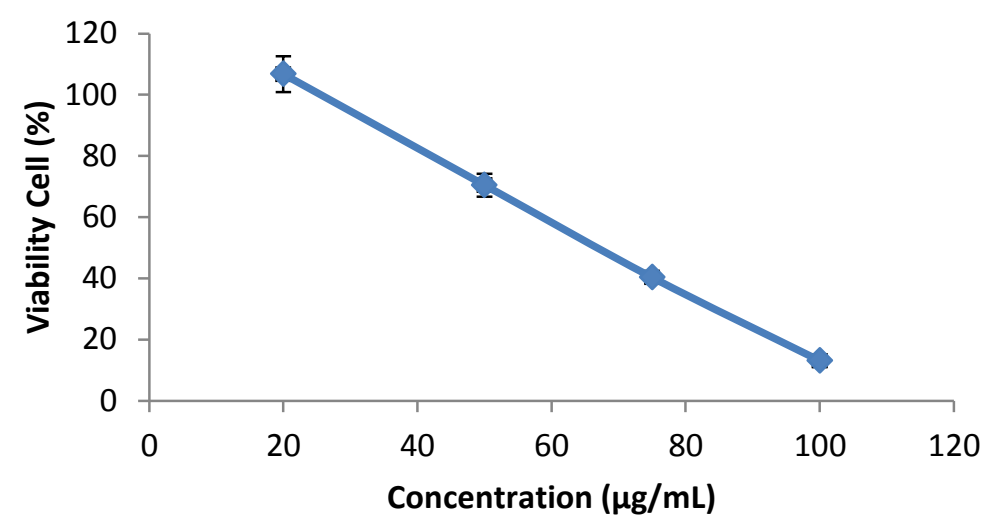

Figure I. Cytotoxic effect of FCB on T47D cells. T47D cells $\left(6 \times 10^{3}\right.$ cells/well) were seeded in 96 wellplate and treated with FCB 20,50,75, and $100 \mu g / \mathrm{mL}$. Then plate was incubated for 24 hours and cells viability was determined by using MTT assay as described in methods. The higher concentration of FCB caused lower cells viability. Data were mean of two replications $x \pm S D(p<0,05)$. IC 50 value was calculated using linier regression and FCB perform cytotoxicity with $\mathrm{IC}_{50}$ value of $68 \mu \mathrm{g} / \mathrm{mL}$.

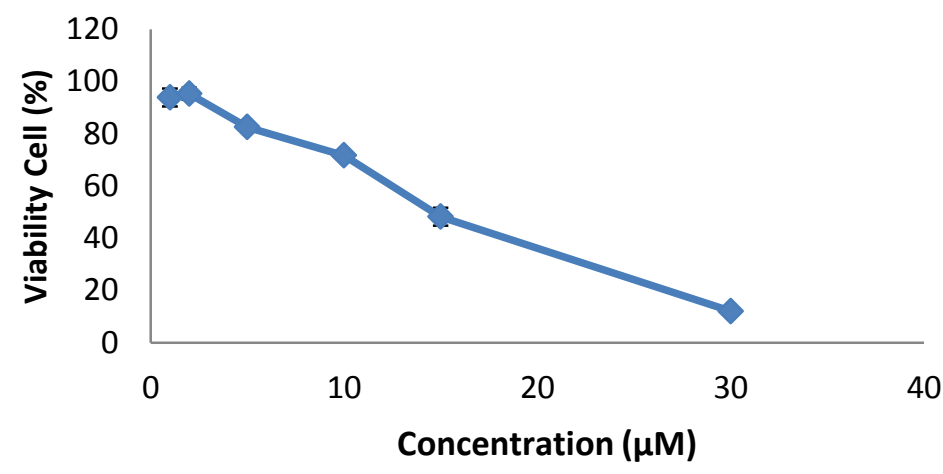

Figure 2. Cytotoxic effect of cisplatin on T47D cells. T47D cells $\left(6 \times 10^{3}\right.$ cells $/$ well) were seeded in 96 wellplate and treated with cisplatin I, 2, 5, 10, 15, and $30 \mu \mathrm{M}$. Then plate was incubated for 24 hours and cells viability was determined by using MTT assay as described in methods. The higher concentration of cisplatin caused lower cells viability. Data were mean of two replications $x \pm S D(p<0,05)$. IC 50 value was calculated using linier regression and cisplatin perform cytotoxicity with IC 50 value of $16 \mu \mathrm{M}$.

Combination of cisplatin and FCB possessed synergistic effect in concentration ratio $1 / 6 ; 1 / 3$; and $1 / 2 \mathrm{IC}_{50}$ (Table 1 ). The most synergistic effect was shown in concentration ratio $1 / 2$ with $C I$ value 0.66 . Dose reduction index (DRI) value of FCB was 3.06, meant that FCB reduced the dose required when combined with cisplatin as much as 3.06 times (from $63.81 \mu \mathrm{g} / \mathrm{mL}$ to $20.85 \mu \mathrm{g} / \mathrm{mL}$ ). It also happened with cisplatin that reduced the dose as much as 2.54 times (from $12.46 \mu \mathrm{M}$ to $4.91 \mu \mathrm{M}$ ). DRI was occured in $50 \%$ inhibition of viable cells. Beside DRI, combination index (CI) value also be analyzed from compusyn. By looking CI value, the combination of drugs can be classified to synergistic, additive or antagonistic based on interactions. From CI values, the combination between cisplatin with FCB had synergistic effect because its CI value was less than 1 (for concentration ratio $1 / 2 \mathrm{IC}_{50}, 1 / 3$ $\mathrm{IC}_{50}$, and $\left.1 / 6 \quad \mathrm{IC}_{50}\right)$. The best $\mathrm{CI}$ value was occured when combined with concentration ratio $1 / 2 \quad \mathrm{IC}_{50}$ with $\mathrm{CI}$ value of 0.66 and decreased the percentage of cell viability up to 23\%. Cell morphology after treatment was observed. There were cell morphology change on treatment combination cisplatin and FCB with concentration ratio $1 / 4$ and $1 / 2 \mathrm{IC}_{50}$ (Fig. 3B, 3C) compared with control cells (Fig. 3A). 
Tabel I. Combination index $(\mathrm{Cl})$ and dose reduction index (DRI) values for FCB, cisplatin, and their combination. Data was obtained from compusyn software

\begin{tabular}{|c|c|c|c|c|c|c|c|}
\hline \multirow{3}{*}{$\%$ sel hidup } & \multirow{3}{*}{ Cl } & \multicolumn{3}{|c|}{ Fraksi Brazilein } & \multicolumn{3}{|c|}{ Cisplatin } \\
\hline & & \multicolumn{2}{|c|}{ Konsentrasi ( $\mu \mathrm{g} / \mathrm{mL})$} & \multirow{2}{*}{ DRI } & \multicolumn{2}{|c|}{ Konsentrasi ( $\mu \mathrm{M})$} & \multirow{2}{*}{ DRI } \\
\hline & & Tunggal & Kombinasi & & Tunggal & Kombinasi & \\
\hline 95 & 1.02 & 30,30 & 5,26 & 5,76 & $\mathrm{I}, 47$ & $\mathrm{I}, 24$ & 1,18 \\
\hline 90 & 0.90 & 36,60 & 7,46 & 4,91 & 2,52 & 1,76 & $\mathrm{I}, 44$ \\
\hline 75 & 0.78 & 48,33 & 12,47 & 3,87 & 6,61 & 2,94 & 1,91 \\
\hline 50 & 0.72 & 63,81 & 20,85 & 3,06 & 12,46 & 4,91 & 2,54 \\
\hline 30 & 0.71 & 79,06 & 31,00 & 2,55 & 23,07 & 7,29 & 3,16 \\
\hline
\end{tabular}
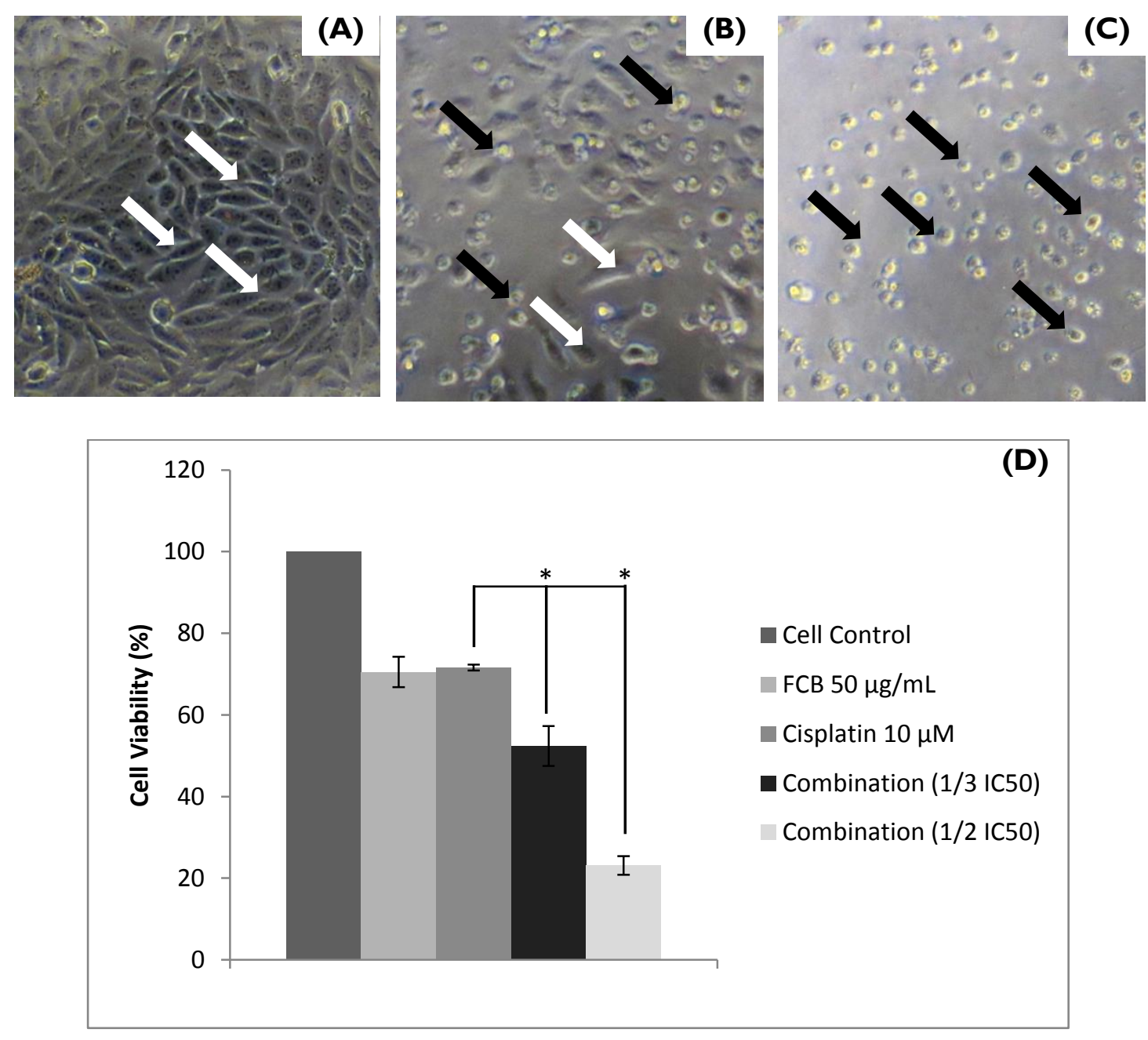

Figure 3. Combinational cytotoxic effect of FCB and cisplatin on T47D cells. T47D cells (6x/03 cells/well) were seeded in 96 wellplate and treated with $\mathrm{FCB}$ and cisplatin in concentration ratio $\mathrm{IC}_{50}: \mathrm{IC}_{50}(\mathrm{I} / 2$; I/3; and I/6 IC 50 ). Then, plate was incubated for 24 hours and cells viability was determined by using MTT assay as described in methods. Combinational treatment altered cells morphology. Cells treated with (A) control cells, (B) combination with concentration ratio $1 / 4 I_{50}$, and (C) combination with concentration ratio $1 / 2 I C_{50}$. White arrows $(\Longrightarrow)$ showed viable cells while black arrows $(\rightarrow)$ showed death cells were observed under light microscope with 100x magnification. Graph (D) showed that combination of FCB and cisplatin decreased cells viability compared to cisplatin single treatment. 
Cytotoxic activity of compound was correlated to its ability to induce apoptosis or inhibit cell cycle. Apoptosis assays' result (Fig. 4) showed that almost $90 \%$ of control cell population was not observed the presence of cell death. While on FCB treatment, apoptosis induction was observed as much as $80.59 \%$ of cell population. On cisplatin treatment, apoptosis induction observed by $80.86 \%$ of cell population. Meanwhile, the percentage of apoptotic cells in combination treatment was 93.93\%. It proved that combination treatment of FCB and cisplatin with 24 hour incubation enhance the ability of cisplatin to induced apoptosis as much as $13 \%$ on T47D breast cancer cells.

(A)
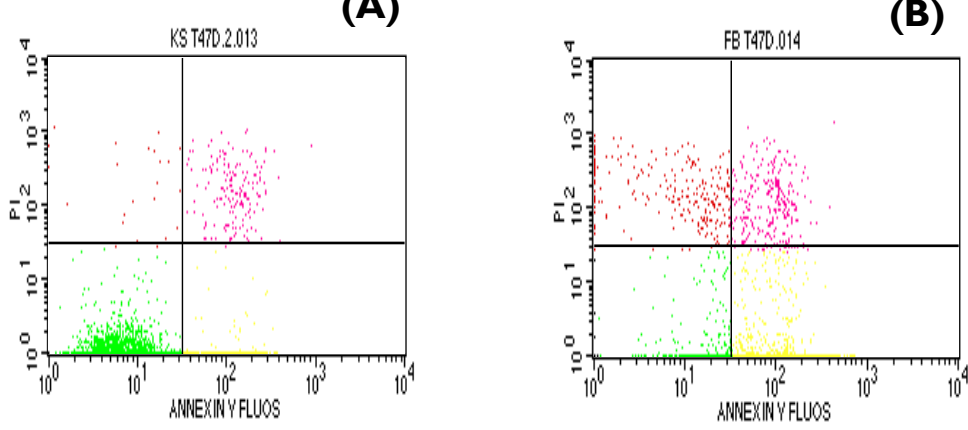

(C)

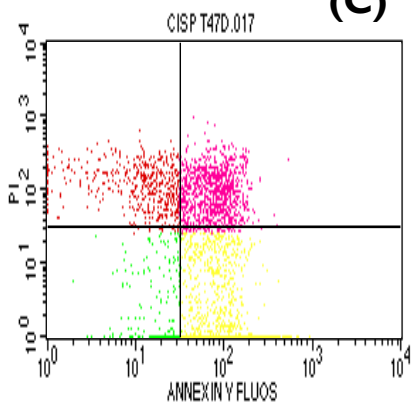

(D)
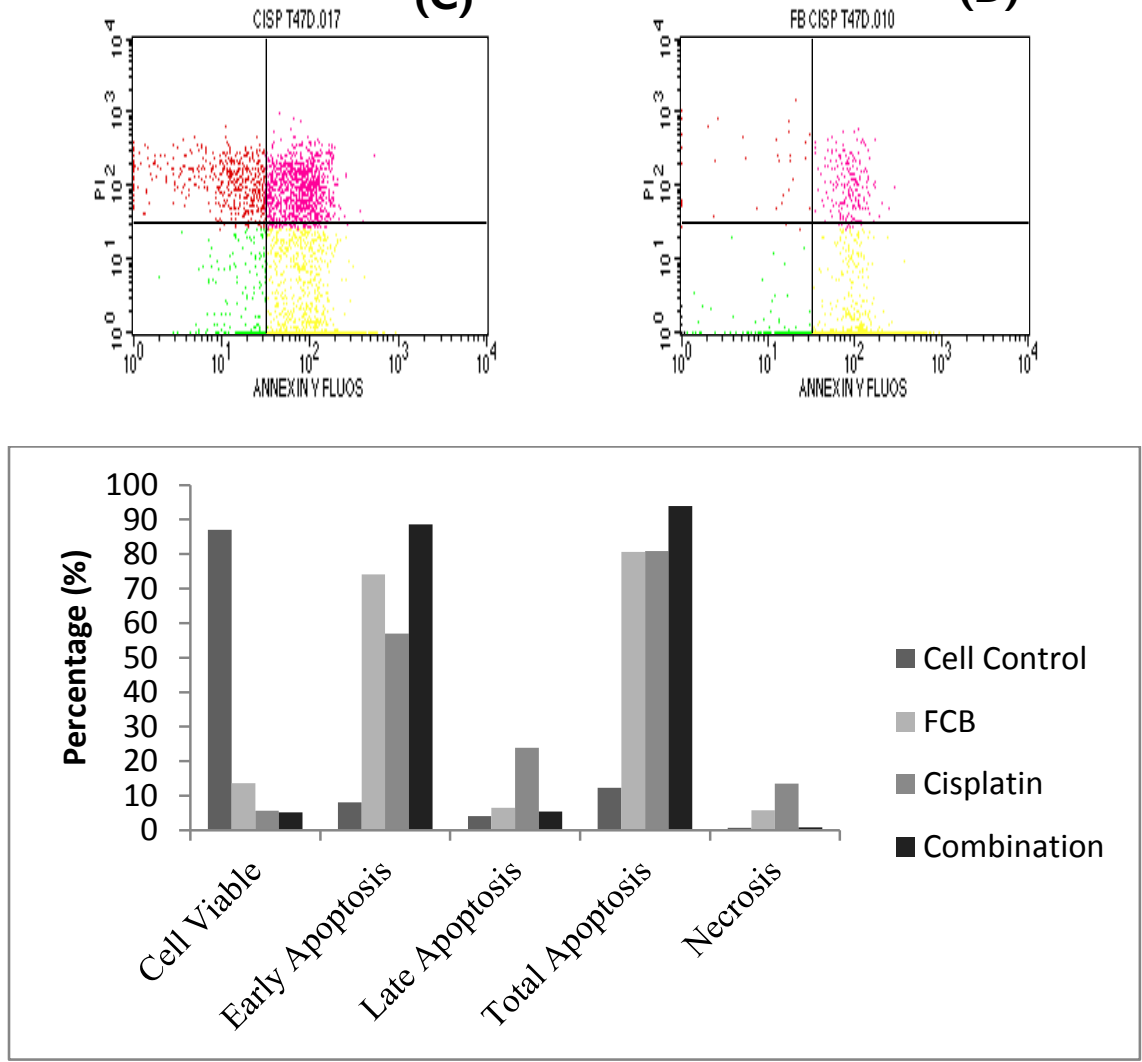

(E)

Figure 4. Effect of combination FCB-cisplatin on T47D cells apoptosis. T47D cells were seeded at $3 \times 10^{5}$ cells/well on 6 wells tissue culture plate, then treated with FCB $1 / 2 I C_{50}$ alone and its combination with cisplatin $1 / 2 I_{50}$. After 24 hours of incubation, cells were harvested as described in methods, added with AnnexinV and PI reagent, then subjected to FACS flowcytometry. Flowcytometric profile of cells treated with (A) control, (B) FCB, (C) cisplatin, and (D) combination of FCB and cisplatin. There are 4 quadrans: lower left (LL) indicates viable cells, lower right (LR) indicating early apoptotic cells, upper left (UL) indicating late apoptotic cell, upper right (UR) indicating necrotic cells. Graph (E) showed the percentage of viability cell of combination FCB and cisplatin induce apoptosis. 
T47D breast cancer cell lines expreses caspase-3 wildtype, caspase-7 wildtype, mutant p53 and ER/PR-positive (Bouker, et al., 2005; Schafer, et al., 2000). In fact, p53 tumor suppressor gene is a gene that plays a role in apoptosis. This $p 53$ gene stimulates expression of Bcl-2 family including Bax, and can bind to one or more anti-apoptotic proteins in mitochondria, such as Bcl-XL (Chipuk, et al., 2003; Marsden, et al., 2002). On the other hand, cisplatin also plays a role in mediating the activation of the p53 protein, which is followed by the occurrence of DNA damage (Tanida, et al., 2012), so the mutation of p53 gene on T47D cells can inhibit cisplatin to induce apoptosis. However, previous studies had proved that the mechanism of cisplatin to induce apoptosis was by causing downregulation of $B c l-2$ gene on MCF 7 cell lines (Thomadaki and Scorilas 2007) and T47D cell lines (Mokhtari, et al., 2012). Other studies had also demonstrated the expression of Bcl-2, Bcl$\mathrm{XL}, \mathrm{BAD}$ and $\mathrm{BAX}$ was regulated by cisplatin (Siervo-Sassi, et al., 2003). So, that is the reason of cisplatin still can induce apoptosis on T47D cell lines, which is expresses mutant $p 53$.

Cytotoxic activity of FCB on T47D cells was expected to be caused by active compounds contained in these fractions, namely brazilin and brazilein. Cytotoxic mechanism of combination FCB and cisplatin occured through apoptosis induction. Apoptosis induction of FCB alone might be related to the mechanism of apoptosis induction from p53 independent. Brazilin which is the main compound from secang's heartwood can activate caspase- 3 and regulate the expression of $\mathrm{Bcl}-2$ family proteins, including Bax, Bcl-x (L), and Bcl-2 on U 266 myeloma cancer cells (Kim, et al., 2012). Brazilin also known could inhibit proliferation of glioblastoma cells (Yen, et al., 2010) and induce apoptosis on glioblastoma cells through activation of caspase-3, followed by poly-(ADP)-ribose polymerase (PARP) cleavage and through the induction of caspase 7 (Lee, et al., 2013; Hengartner, 2000). In addition, brazilin also increased the population of glioblastoma cells in cell cycle sub-G1 area (Lee, et al., 2013). While the other major compound of secang's heartwood, like brazilein, also known could increase the activation of caspase- 9 and caspase- 3 , induce PARP cleavage and cause down-regulation of survivin protein on HepG2 liver cancer cells
(Zhong, et al., 2009). On MCF-7 breast cancer cells, brazilein also could induce apoptosis through inhibition of survivin expression (Tao, et al., 2011). Brazilein also could inhibit NF-кB activation via PI3K/Akt pathway inactivation and p38 MAPK on MDA-MB-23 cells (Hsieh, et al., 2013). These mechanisms might be responsible in apoptosis induction of secang's heartwood on T47D cell lines. Thus, further study is still needed to be conducted.

\section{CONCLUSION}

We summarized that FCB is able to enhance the cytotoxic effects of cisplatin by inducing apoptosis

\section{ACKNOWLEDGEMENT}

We acknowledge Indonesian Directorate General of Higher Education (DIKTI) for funding this research.

\section{REFERENCES}

Bouker, K.B., Skaar, T.D., Riggins, R.B., Harburger, D.S., Fernandez, D.R., Zwart, A., et al., 2005, Interferon Regulatory Factor-I (IRF-I) Exhibits Tumor Supressor Activities in Breast Cancer Associated with Caspase Avtivation and Induction of Apoptosis, Carcinogenesis, 26(9), I527-I535.

Chipuk, J.E., Maurer, U., Green, D.R. and Schuler, M., 2003, Pharmacologic Activation Of P53 Elicits Bax-Dependent Apoptosis In The Absence Of Transcription, Cancer Cell, 4(5), 37I-38I.

Dhar, S., Kolishetti, N., Lippard, S.J. and Farokhzad, O.C., 20II, Targeted Delivery of a Cisplatin Prodrug for Safer and More Effective Prostate Cancer Therapy In Vivo, Proc. Natl. Acad. Sci. USA, I08(5), I850-I855.

Hengartner, M.O., 2000, The Biochemistry of Apoptosis, Nature, 407(6805): 770-776.

Hsieh, C.Y., Tsai, P.C., Chu, C.L., Chang, F.R., Chang, L.S., Wu, Y.C., et al., 2013, Brazilein Suppresses Migration and Invasion of MDA-MB-23। Breast Cancer Cells, Chem. Biol. Interact., 204(2), I05II5.

Ismael, G.F., Rosa, D.D., Mano, M.S. and Awada, A., 2008, Novel Cytotoxic 
Drugs: Old Challenges, New Solutions, Cancer Treat. Rev., 34(I), 8I-9I.

Kim, B., Kim, S.H., Jeong, S.J., Sohn, E.J., Jung, J.H., Lee, M.H., et al., 20I2, Brazilin Induces Apoptosis and G2/M Arrest Via Inactivation of Histone Deacetylase in Multiple Myeloma U266 Cells, J. Agric. Food Chem., 60(39), 9882-9889.

Lee, D.Y., Lee, M.K., Kim, G.S., Noh, H.J. and Lee, M.H., 2013, Brazilin Inhibits Growth and Induces Apoptosis in Human Glioblastoma Cells, Molecules, I8, 24492457.

Liang, C.H., Chan, L.P., Chou, T.H., Chiang, F.Y., Yen, C.M., Chen, P.J., et al., 2013, Brazilein from Caesalpinia sappan $L$. Antioxidant Inhibits Adipocyte Differentiation and Induces Apoptosis Through Caspase-3 Activity and Anthelmintic Activities Against Hymenolepis Nana and Anisakis Simplex, Evid. Based Complement. Alternat. Med., 20I3(20I3), 864892.

Marsden, V.S., O'Connor, Liam., O'Reilly, L.A., Silke, J., Metcalf, D., Ekert, P.G., et al., 2002, Apoptosis Initiated By Bcl-2Regulated Caspase Activation Independently Of The Cytochrome C/Apaf-I/Caspase-9 Apoptosome, Nature, 4I 9(6907), 634-637.

Milosavlievic, N., Duranton, C., Djerbi, N., Puech, P., Gounon,P., LagadicGossmann, D., et al., 20I0, Nongenomic Effects Of Cisplatin: Acute Inhibition Of Mechanosensitive Transporters And Channels Without Actin Remodeling, Cancer Res., 70(19), 75|4-7522.

Mokhtari, M.J., Azim, A., Mehrdad, H., Gholamreza, J., Reza, M., Mohammad, R.M., et al., 2012, Cisplatin Induces Down Regulation of BCL2 in T47D Breast Cancer Cell Line, Advanced Studies in Biology, 4(I), 19-25.

Nurulita, N.A. and Muflih, Y.A., 2006, Efek Sitotoksik Ekstrak Metanol Kayu Secang (Caesalpinia sappan L.) pada Sel Kanker Payudara T47D melalui Induksi Apoptosis, PHARMACY, 4(I), I-9.

Omoyeni, O.A., Meyer, M., Iwuoha, E., Green, I. and Hussein, A.A., 2014, An Unusual 2,3-Secotaraxerene and Other Cytotoxic Triterpenoids from Pleiocarpa pycnantha (Apocynaceae) Leaves Collected from Nigeria, Molecules, I9(3), 3389-3400.
Schafer, J.M., Lee, E.S., O'Regan, R.M., Yao, K., and Jordan, V.C., 2000, Rapid Development of Tamoxifen-stimulated Mutant p53 Breast Tumors (T47D) in Athymic Mice, Clin. Cancer Res., 6(II), 4373-4380.

Sharma, G., Tyagi, A.K., Singh, R.P., Chan, D.C.F. and Agarwal, R., 2004, Synergistic Anti-Cancer Effect of Grape Seed Extract and Conventional Cytotoxic Agent Doxorubicin Against Human Breast Carcinoma Cells, Breast Cancer Res. Treat., 85(I), I-I2.

Shimokawa, T., Kinjo, J., Yamahara, J., Yamahara, M. and Nohara, T., 1985, Two Novel Aromatic Compounds from Caesalpinia sappan, Chem. Pharm. Bull., 33(8), 3545-3547.

Siervo-Sassi, R.R., Marrangoni, A.M., Feng, X., Naoumova, N., Winans, M., Edwards, R.P., Lokshin, A., 2003, Physiological and Molecular effects of Apo2L/TRAIL and Cisplatin in Ovarian Carcinoma Cell Lines, Cancer Lett., 190, 61-72.

Tanida, S., Tsutomu, M., Keiji, O., Hironobu, T., Takeshi, K., Hiromi, K., et al., 2012, Mechanisms of Cisplatin-Induced Apoptosis and of Cisplatin Sensitivity: Potential of BINI to Act as a Potent Predictor of Cisplatin Sensitivity in Gastric Cancer Treatment, Int. J. Surg. Oncol., 20 I 2(20I2), I-9.

Taoa Li-yang, Li Jian-ying, and Zhang Jian-ye, 20II, Brazilein Induced Cells Apoptosis in Human Breast Cancer MCF-7 Cells and Its Action Mechanism, Journal of Sun Yat-Sen University, 32(4), 449-453.

Thomadaki, H. and Scorilas, A., 2007, Breast Cancer Cells Response to the Antineoplastic Agents Cisplatin, Carboplatin, and Doxorubicin at the mRNA Expression Levels of Distinct Apoptosis-related Genes, Including the New Member, BCL2LI2, Ann. N. Y. Acad. Sci., 1095, 35-44.

Tsimberidou A.M., F. Braiteh, D.J. Stewart, and R. Kurzrock, 2009, Ultimate Fate of Oncology Drugs Approved by The US Food and Drug Administration Without a Randomized Trial, J. Clin. Oncol., 27(36), 6243-6250.

Washiyama, M., Sasaki, Y., Hosokawa, T. and Nagumo, S., 2009, Anti-inflammatory Constituents of Sappan Lignum, Biol. Pharm. Bull., 32(5), 94I-944. 
Yan X., W. Wang, D. Xing, Y. Zhao, and L. Du, 2005, Development and Optimization of a Method for the Analysis of Brazilein by HPLC with Electrochemical Detection, J. Chromatogr. A., I077(I), 44-48.

Yen, C.T., Nakagawa-Goto, K., Hwang, T.L., Wu, P.C., Morris-Natschke, S.L., Lai, W.C., et al., 2010, Antitumor Agents. 27I. Total Synthesis and Evaluation of
Brazilein and Analogs as Antiinflammatory and Cytotoxic Agents, Bioorg. Med. Chem. Lett., 20(3), I0371039.

Zhong, X., Wu, B., Pan, Y.J. and Zheng, S., 2009, Brazilein Inhibits Survivin Protein and mRNA Expression and Induces Apoptosis in Hepatocellular Carcinoma HepG2 Cells, Neoplasma, 56(5), 387-92. 